\title{
DISTANT DETERMINATION OF BILIRUBIN DISTRIBUTION IN SKIN BY MULTI-SPECTRAL IMAGING
}

\author{
I. Saknite, D. Jakovels, J. Spigulis \\ Bio-Optics and Fibre Optics Laboratory, \\ Institute of Atomic Physics and Spectroscopy, University of Latvia, \\ 19 Raina Blvd., LV-1586, Riga, LATVIA \\ e-mail: inga.saknite@gmail.com
}

\begin{abstract}
For mapping the bilirubin distribution in bruised skin the multi-spectral imaging technique was employed, which made it possible to observe temporal changes of the bilirubin content in skin photo-types II and III. The obtained results confirm the clinical potential of this technique for skin bilirubin diagnostics.

Key words: multi-spectral imaging, mapping of skin chromophore distribution, bilirubin.
\end{abstract}

\section{INTRODUCTION}

Determination of the bilirubin content and distribution in skin is crucial for the diagnostics of infant bilirubinemia, the follow-up of wound healing after surgeries, the estimation of the age of bruises in forensic medicine, etc. The skin colour in these cases is mostly affected by haemoglobin and its breakdown product bilirubin.

Visual assessment is not accurate enough to determine the age of a bruise [1]. The diffuse reflectance spectroscopy has been successfully used to analyse the temporal changes of bilirubin content in bruises [2-4]. With this technique it was possible to determine the age of a bruise with the accuracy of one day [5]. The multi-spectral imaging combines spectroscopic and imaging techniques, being therefore useful for distant mapping of skin chromophores (haemoglobin and melanin) [6]. In the present work, this technology is further developed in order to employ it for mapping the skin bilirubin distribution.

\section{EXPERIMENTAL}

The main area of the study was bruises on human skin (which were tested at different times after they had been received) in order to analyze changes in the bilirubin concentration over time. A computer-aided multi-spectral imaging system Nuance 2.4 (Cambridge Research \& Instrumentation, Inc., USA) with white LED illumination was used to obtain image cubes of human skin in the spectral range of 450-750 nm (Fig. 1). Light propagation in skin was approximated by BeerLambert's law [7]. The measured absorption spectrum was expressed as a superposition of absorption spectra of four chromophores (oxyhaemoglobin, deoxyhaemoglobin, melanin and bilirubin). Relative chromophore concentration values were obtained solving the least-squares problem, and the distribution maps for corresponding parameters were constructed. 


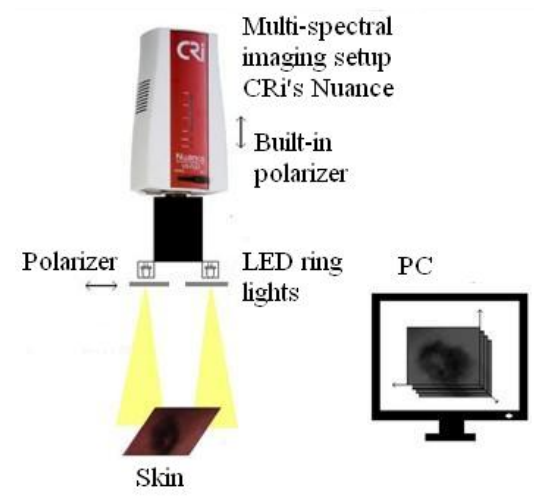

Fig. 1. The experimental setup.

As the light source, a 24 warm-white LED ring was used. The normalized LED spectrum in comparison with the spectra of four chromophores is shown in Fig. 2 [7].

The cross-polarization technique was applied in order to reduce the specular reflection, for which a linear polarizer was placed in front of the light source orthogonally to the built-in polarizer [8].

The liquid crystal tuneable interference filter was used for spectral scanning. The light penetrability in skin differs for different wavelengths [9]. Thus, various exposure times (1...6 miliseconds) were taken for obtaining monochromatic images at different wavelengths.



Fig. 2. LED emission spectrum in comparison with the absorption spectra of chromophores.

The skin area under study was $\sim 50 \times 35 \mathrm{~mm} ; 4 \times 4$ pixel binning was used to speed up the image processing, while the resolution was decreased to $0.15 \mathrm{~mm} /$ pixel $(348 \times 256$ pixel image).

A white paper sheet was taken for reference measurements. Because the paper is not an ideal reflector, a correction was made for each acquired image. The correction was made comparing the paper sheet with the standard white reference tile (Avantis [10]). 
The total time to take an image cube of the spectral range of 450-750 nm with a spectral resolution of $10 \mathrm{~nm}$ was approx. 15 seconds.

The image processing was performed in Matlab. A built-in function $L S Q R$ was applied to solve the relevant linear equation set by the least squares method. In order to increase the speed of the algorithm, the image resolution was reduced 5 times, so for the bilirubin concentration maps it was $0.75 \mathrm{~mm} / \mathrm{px}(70 \times 51$ pixel images), and the maps were generated in about 6 seconds.

The Beer-Lambert law was employed to describe the interaction of light with tissue. The optical density (OD) values were derived from the law as follows.

$$
O D_{\lambda}=\lg \frac{I_{0}(\lambda)}{I(\lambda)}
$$

where $I_{0}$ is the reflection intensity from the white reference (the initial radiation),

$I$ is the intensity of light reflected back from the skin.

The predicted OD spectrum is expressed as superposition of the spectra of four chromophores:

$$
O D_{\lambda}=\varepsilon_{O H}(\lambda) \cdot C_{O H}+\varepsilon_{D O H}(\lambda) \cdot C_{D O H}+\varepsilon_{M e l}(\lambda) \cdot C_{M e l}+\varepsilon_{B i l}(\lambda) \cdot C_{B i l},
$$

where $\varepsilon$ is the molar extinction coefficient (the tabular values for each chromophore are shown in Fig. 2 [11]),

$C$ is the relative concentration for each chromophore.

As these concentration values are dependent on the optical path length of radiation in the tissue, a correction coefficient was applied (taken from [12]).

The relative concentration values for each pixel of each chromophore were obtained solving the problem by the least squares method in Matlab, and the distribution maps for relative bilirubin concentration were constructed.

20 bruises were observed in time, and the total number of 51 image cubes were obtained and analyzed. Eight volunteers participated in the experiment: 7 females and 1 male, aged from 20 to 32 years, 7 individuals with skin type II and 1 with skin type III (Fitzpatrick's scale).

The maps of relative bilirubin concentration were analysed in time, and its average values for a particular square of the bruise region were observed as a function of time.

\section{RESULTS AND DISCUSSION}

The maps of the bilirubin concentration show that it increases in time for most of the bruises observed in the experiment. The maps showing the bilirubin relative concentration changes in time are shown in Fig. 3. To analyse quantitative concentration changes in time, a region of a particular square of all maps was chosen and the average relative concentration value was calculated. The relative bilirubin concentration changes as a function of time are displayed in Fig. 4.

When comparing all obtained average values of relative concentration of bilirubin in bruises and normal skin, a difference can be seen: these values for skin type III appear to be greater than for skin type II, both in normal and bruised skin (Fig. 5). 


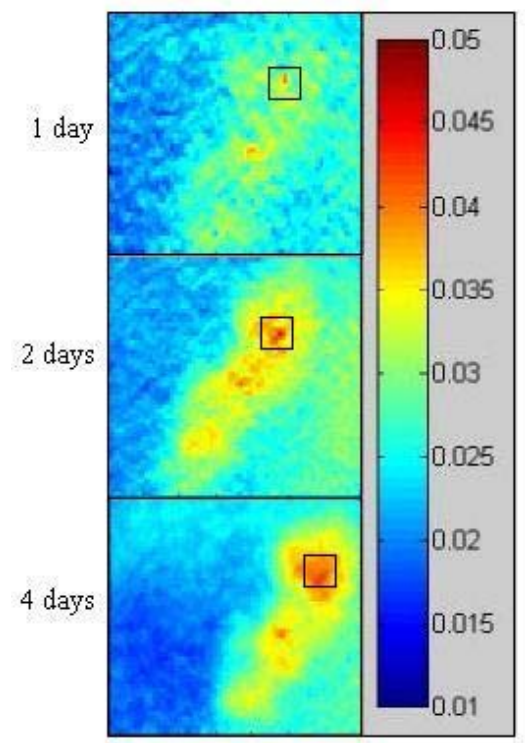

Fig. 3. Maps of relative bilirubin concentration changes over time (female, 21 years old, II skin type).

\section{Bruise on arm (female, 21 years old, II skin type)}

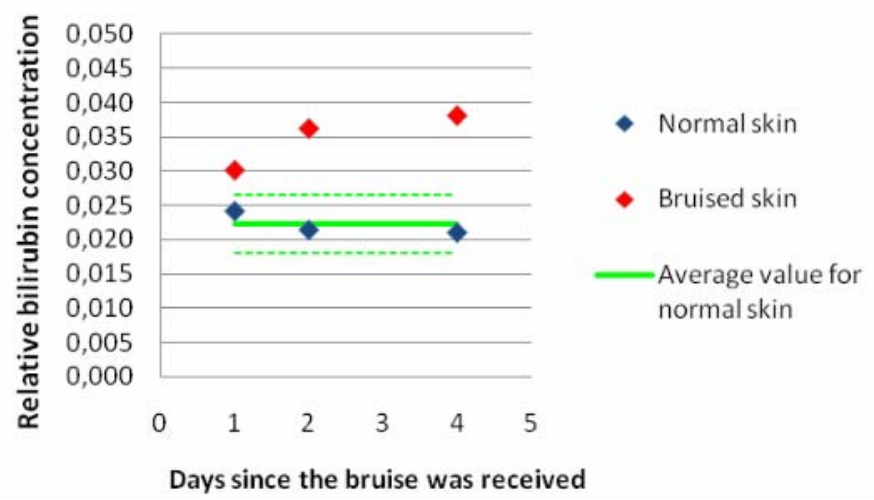

Fig. 4. Relative bilirubin concentration changes as a function of time.

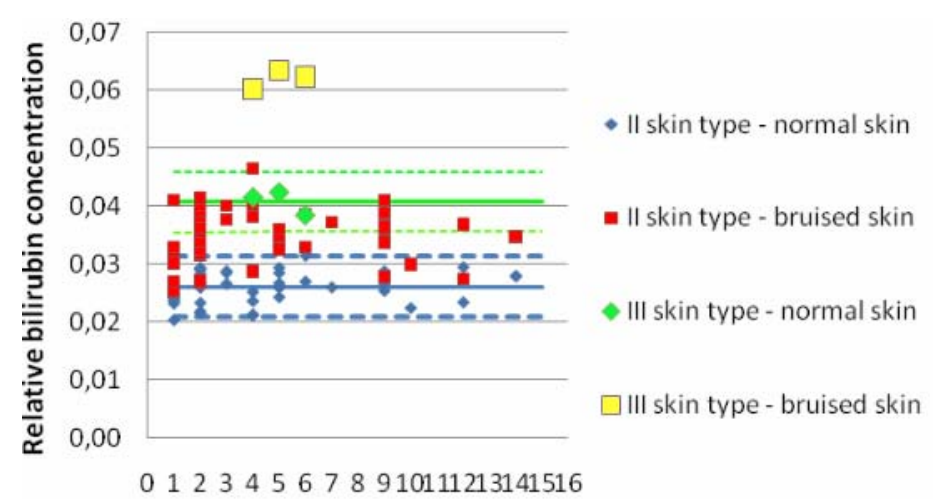

\section{Days since the bruise was received}

Fig. 5. Comparison of relative bilirubin concentration for two types of skin. 


\section{CONCLUSIONS}

A simplified model with a relevant algorithm was used to obtain relative bilirubin concentration maps. The results show that it is possible to observe temporal changes in the bilirubin concentration in bruised skin. As was expected [5], this concentration increases in time during the first days after the bruise has been received. A difference in relative bilirubin concentrations between skin types II and III was observed, which can be assigned to the influence of melanin on the skin parameters and is to be studied further.

\section{REFERENCES}

1. Pilling, M.L., Vanezis, P., Perrett, D., \& Johnston, A. (2010). Visual assessment of the timing of bruising by forensic experts. J. Forensic. Leg. Med., 17 (3), 143-149.

2. Ruvolo Jr., E.C., Bargo, P.R., Dietz, T., Scamuffa, R., Shoemaker, K., DiBernardo, B., \& Kollias, N. (2010). Use of spectral imaging for documentation of skin parameters in face lift procedure. Proc. SPIE, 7548, 75480A.

3. Duckworth, M.G., Caspall, J.J., Mappus, R.L., Kong, L., Yi, D., \& Springle, S.H. (2008). Bruise chromophore concentrations over time. Proc. SPIE, 6915, 69152S.

4. Springle, S., Yi, D., Caspall, J., Linden, M., Kong, L., \& Duckworth, M.G. (2007). Multispectral image analysis of bruise age. Proc. SPIE, 6514, 65142T.

5. Randeberg, L.L., Haugen, O.A., Haaverstad, R., \& Svaasand, L.O. (2006). A novel approach to age determination of traumatic injuries by reflectance spectroscopy. Las. Surg. Medic., 38, $277-289$.

6. Jakovels, D., Spigulis, J., \& Saknite, I. (2010). Multi-spectral mapping of in vivo skin haemoglobin and melanin. Proc. SPIE, 7715, $77152 Z$.

7. Saknīte, I. (2010). Bilirubīna un melanīna sadalījuma noteikšana ādā ar multispektrālās attēlošanas metodi: bakalaura darbs. LU Fizikas un matemātikas fakultāte (in Latvian).

8. Demos, S.G., \& Alfano, R.R. (1997). Optical polarization imaging. Appl. Opt., 36 (1), 150-155.

9. VariSpec Brochure. Research and Instrumentation, Inc. [18.05.2010.]. http://www.criinc.com/support/components.asp.

10. Avantes website - [17.05.2010.]. http://www.avantes.com/Colorimetry/WhiteReference-Tile/Detailed-product-flyer.html.

11. Oregon Medical Laser Center website - [12.05.2010.]. http://omlc.ogi.edu/spectra/.

12. Priedīitis, K. (2004). Fotopletizmogrāfiskā signāla datorapstrāde un analīze: maǵistra darbs. LU Fizikas un matemātikas fakultāte (in Latvian).

\section{BILIRUBĪNA SADALĪJUMA NOTEIKŠANA ĀDĀ AR MULTISPEKTRĀLĀS ATTĒLOŠANAS METODI}

\section{Saknīte, D. Jakovels, J. Spīgulis}

Kopsavilkums

Darba mērķis bija izveidot iespējami vienkāršu metodi ādas hromoforas bilirubīna in vivo kartēšanai no attāluma. Ar neinvazīvu optisko metodi - multispektrālo attēlošanu - tika novērota 20 zilumu attīstība laikā, kopā uzņemot 51 attēlu masīvu. Gaismas mijiedarbības ar ādu aprakstam tika izmantota difūzi atstarotās gaismas teorija, un ar Nuance 2.4 multispektrālās attēlošanas sistēmu komplektā ar datoru tika iegūtas ādas attēlu optiskā blīvuma (OD) vērtības, kas iegūtas kā sākotnējā starojuma intensitātes un no ādas virsmas atpakal atstarotās 
gaismas intensitātes attiecība. Izmantojot Bēra-Lamberta likumu, OD spektrs tika izteikts kā četru ādā esošu hromoforu - oksihemoglobīna, deoksihemoglobīna, melanīna un bilirubīna - atsevišḳo spektru superpozīcija. Ar mazāko kvadrātu metodi programmā Matlab tika aprēḳinātas relatīvās bilirubīna koncentrācijas vērtības, iegūstot koncentrāciju sadalījuma kartes.

Pierādīts, ka ar multispektrālo attēlošanu iespējams neinvazīvi veikt ādas hromoforas bilirubīna kartěšanu un novērot bilirubīna koncentrācijas izmainas laikā. Pirmajās dienās pēc ziluma iegūšanas bilirubīna koncentrācija laikā pieaug, kas atbilst literatūrā pieejam.

11.01.2011. 